\title{
Public works: Building a Monument to Modern Buenos Aires.
}

\author{
Obras públicas: Construir un monumento a la Buenos \\ Aires moderna.
}

\begin{abstract}
This paper closely reads the Obelisk in the context of the public works projects under construction at the time of Buenos Aires's fourth centennial in 1936. The projects to modernize the city, dating even from before the turn of the century, had indelibly changed its form, extending its paved arteries out and around the city limits and connecting distant parts of the city by subway. Previous writing on the Obelisk has privileged closed thinking about the monument from its viewing platform at its tip. I proposed instead a perspective that arises from below, starting with its subterranean and street-level spaces. Considering the Obelisk in the context of its contemporary monumental infrastructures and in juxtaposition to Barthes' writing on the Eiffel Tower allows for an assessment of its currency as a symbol that is sustained by the many quotidian actions that occur around it. Although there were concrete figures behind its establishment in the city, continued engagement with the monument by a host of organizations and individuals have brought it forward as a way of seeing and envisioning the future of Buenos Aires.
\end{abstract}

Keywords

Urbanism, Buenos Aires, Monuments, Infrastructure, Public Works, Argentine Architecture.

\section{Resumen}

Este ensayo lee al Obelisco de Buenos Aires en el contexto de las obras públicas construidas alrededor del cuarto centenario de la ciudad en 1936. Los proyectos de modernización de Buenos Aires, que datan incluso antes del cambio de siglo, habían cambiado su forma de manera indeleble. Las arterias pavimentadas se extendieron a lo largo de los límites de la ciudad y el subterráneo empezó a contectar sus barrios más alejados. La literatura sobre el Obelisco ha privilegiado un pensamiento cerrado acerca del monumento que prioriza una perspectiva desde su punta. Este ensayo, en cambio, propone una perspectiva que surge de 
abajo, empezando con el subterráneo y los espacios al nivel de su base. Considero el Obelisco en el contexto de sus infraestructuras monumentales contemporáneos y en yuxtaposición con la teoría de monumentalidad propuesto por Barthes en su ensayo sobre la Torre Eiffel. Estas consideraciones permiten una evaluación de su vigencia como símbolo que se sostiene a través de las acciones cotidianas que ocurren en sus alrededores. Aunque hubo figuras concretas detrás de su construcción al centro de la ciudad, las interacciones sostenidas de una multiplicidad de organizaciones y individuos con el monumento lo han propuesto como un modo de ver y proyectar el futuro de Buenos Aires.

Palabras claves Urbanismo, Buenos Aires, Monumentos, Infraestructura, Obras públicas, Arquitectura Argentina.

A long shot of the Obelisk, the monument transfixed in the flood of cars driving down Avenida Nueve de Julio. ${ }^{1}$ Another shot, leading the viewer down Avenida Corrientes busy still in the late evening. And another--pedestrians crossing Avenida Nueve de Julio, walking towards the Plaza de la Republica circling the monument. A group of three sits on the stone benches surrounding the plaza, looking bored. The young woman and two men are waiting for someone to appear--two people in fact, the woman's husband and another friend, shown in the next shot to be chatting with a cab driver on the other side of the avenue. They sit, trying to keep warm on the cold winter night, and decide what they're going to eat. After leaving the plaza, robbing a disabled street performer for money to buy their pizza, beer and cigarettes for the night, they return to the Obelisk, and decide to break in. Leaving the young woman, Sandra, below, too pregnant to climb over the protective fence, they kick down the door and light discarded paper and wood to illuminate the interior and the way up. Trompa, one of the group, makes his way to the window, and looks out, remarking: "No se ve ni un carajo" [You can't see shit]. Few have had the privilege of making it to the top of the monument which looks out over and contemplates the city from the inside. Reflected upon at length and through a variety of discourses, many have attempted to remake the Obelisk to consider its relationship to the city that it celebrates. This essay,

\footnotetext{
${ }^{1}$ See Figure 1.
} 
nevertheless, traces its critical development to films and performance art like Pizza, Birra, Faso, the Obelisks of Marta Minjuín and the recent work, La democracia del símbolo by Leandro Erlich. Taking these pieces and narratives as a starting point, the question is--how can we consider the city from the Obelisk?

The Obelisk of Buenos Aires was built in 1936 under the administration of Mariano de Vedia y Mitre to commemorate the 400th anniversary of the founding ${ }^{2}$ of the city by Pedro de Mendoza. Designed by Alberto Prebisch, a noted modernist architect and architecture and urbanism critic from the northern province of Tucumán, the Obelisk was meant to serve as a monument to the city that Buenos Aires was becoming and had in many ways already become. In the decades prior to the Obelisk's construction, and especially the few years before its emergence in the city center, Buenos Aires had undergone rapid and deep changes that took it from being la Gran Aldea [the Big Village] to advertising itself as one of the most modern cities in the world. Many of these changes were propelled by the demographic upheaval beginning in the late 19th century--new kinds of services and infrastructures were introduced to manage an exploding population through housing, transportation, sanitation, manufacturing and state-sponsored culture. ${ }^{3}$ Vedia y Mitre's administration in particular and the city council of the time accelerated some of these changes--the development of new subway and train lines, highways, gas lines and the electrification of the city are just a few examples. And yet, while these public works were all monumental projects in and of themselves, there was no material symbol to herald and represent the

\footnotetext{
2 Pedro de Mendoza's founding of the city has been questioned by various critics, among them, Graciela Silvestri, whose account of the early years of Spanish presence and colonies in the Rio de la Plata region in El color del rio cast serious doubt upon the size, duration and importance of the settlement named Santa Maria de los Buenosayres. She points to the later, second founding of Buenos Aires by Juan de Garay in 1580 on behalf of the Viceroyalty of Peru as the effective beginning of the port that would later grow into a city. However, despite these revisions to the historical account, Mendoza's arrival at what would later become Buenos Aires is taken both popularly and by the state as the city's inception.

${ }^{3}$ In El color del río: historia cultural del paisaje del riachuelo, Graciela Silvestri gives a detailed account of how demographic growth from the late 19th Century to the early-mid 20th Century impacted the built environment of Buenos Aires, especially in the port areas at the city's eastern edge.
} 
construction of the city of the future, and no means of interpreting what these projects could mean on a national scale.

Mariano de Vedia y Mitre's Buenos Aires (1932-1938) was one of great infrastructural upheaval, and has been characterized by its vigorous construction and establishment of public works in the city. Among the projects continued and begun during this period are the expanded electrification and gasification of the city, the opening of Diagonal Norte continued from the previous fourteen administrations, ${ }^{4}$ the expansion of Calle Cerrito and Calle Carlos Pellegrini into Avenida Nueve de Julio and the continued construction and elongation of the subway lines, as well as the beginnings of the parkway Avenida General Paz, that would be finished several years later in 1941. The city during the time of the construction of the Obelisk was still the city of immigrants it had become at the end of the 1800s and with these still unwieldy masses, new ideas of the state and its role in managing these masses came to the fore. The responsibility of manipulating the city's built environment and creating new services was increasingly viewed as a part of a city- and nation-building project. ${ }^{5}$ However, the purpose of these changes and the kind of city Buenos Aires was to grow into was the subject of intense debate.

On February 3rd, 1936, Mariano de Vedia y Mitre decreed that the Obelisk of Buenos Aires should be built at the crossing of Diagonal Norte, Avenida Corrientes, and the still under construction, Avenida Nueve de Julio (Walter 190). The city council had been in recess, but Vedia y Mitre's close relationship with President Agustín P. Justo, ${ }^{6}$ almost certainly assured him

${ }^{4}$ Beginning under Joaquín de Anchorena's administration in January 1912 with the national Congress' legislative approval of the construction, this project continued haltingly through to Vedia y Mitre's administration in 1936. See Walter, 37-42 for an account of the the genesis of the Diagonal Norte/Avenida Roque Saenz Peña project.

${ }^{5}$ See Diego Armus' The Ailing City: Health, Tuberculosis and Culture in Buenos Aires, especially his chapter, "The Fight Against Tuberculosis and the Culture of Hygiene" for a detailed account of how this kind of ideology impacted the way the role of the state was conceived of in relation to the fields medicine, architecture, and urban planning during the 1930s.

${ }^{6}$ Agustín Pedro Justo, though elected to office, has been supposed of promoting electoral fraud in support of his presidency. Justo, like Vedia y Mitre, was a participant in the 1930 coup that 
approval of his plan for the city at the highest level of government, during a time of notable corruption and backroom political dealings. Several months later, Vedia y Mitre contracted architect Alberto Prebisch to design the plans for the monument. ${ }^{7}$ In the midst of the avenue clearing that required a swath of buildings extending on a straight axis from the northern side of the city down to a central point from the city's southern border, the Obelisk was quickly stacked to its current height ${ }^{8}$ and inaugurated with much fanfare.

In the following pages of this paper, I will reflect on how, placing the Obelisk in the context of the public works projects taking place around Buenos Aires' fourth centennial, we can understand the monument as a city-making technology. This paper comprises a brief history of the city of Buenos Aires leading up to the construction of the monument; an evaluation of the the relationship between the Obelisk's architect, Alberto Prebisch's project for a new city, the Ciudad Azucarera in Tucumán, Argentina and the project of urban renewal at the center of Buenos Aires; and finally, through a critique of Roland Barthes' essay on monuments, "The Eiffel Tower," a theory of the Obelisk and Buenos Aires. In that sense, I will argue that Obelisk of Buenos Aires is only accessible as a symbol and perspective onto the city when accessed from the concrete public works projects that it was meant to represent.

\section{Prebisch's urbanism and the monument.}

I would like to trace an antecedent to the Obelisk of Buenos Aires and the urban renewal public works built around it in Alberto Prebisch and Ernesto Vautier's unrealized 1924 Ciudad Azucarera, a plan for a workers' village in the

removed Hipólito Yrigoyen of the Radical Party, in favor of the general José Félix Uriburu, inaugurating what has since been known as "La Década Infame"(The Infamous Decade), following the scholarship of José Luis Torre in his 1945 classic La Década Infame. Justo had previously been a general and Minister of War under Marcelo T. de Alvear in the early 1920s.

7 Chrisitan Ferrer suggests that the idea of the Obelisk form was advanced by close friend of Prebisch and Vedia y Mitre-and also his municipal secretary--, Atilio dell'Oro Maini.

${ }^{8} 67.5$ meters. See Figure 2. 
capital of Prebisch's native province of Tucumán. This particular project is important to understand the urban modernization project that the mayor, Vedia y Mitre, hoped to achieve through Prebisch's monument because it established a morality that would justify razing a significant percentage of the city center. As Adrían Gorelik remarks in his seminal essay on Buenos Aires' fourth centenary, the idea that material progress must be married with spiritual progress was an especial topic of debate at the time as both Argentina's first centennial in 1916 and the City of Buenos Aires' fourth centennial in 1936 stirred debates on the futures of both the nation and the city (Gorelik 185). The ideological project in Prebisch and Vautier's worker's village for Tucumán was rooted both in Le Corbusier's idea that social architecture and urbanism could be fail safes against communism and Tony Garnier's 1917 Cité Industrielle, a plan for a socialist worker's city in the south of France. Prebisch's political ideas on architecture were more closely aligned to Le Corbusier's, but saw in Garnier's Cité Industrielle project a means of ordering the city spatially to achieve a new morality.

La Ciudad Azucarera, designed with his partner Ernesto Vautier, had a definite impact on the later design of the Obelisk. This glimpse of the architect partners' urbanism through the Ciudad Azucarera is important to understanding Prebisch's obelisk because it establishes the young architects' way of addressing the relationship between their aesthetic project and the urban politics. Considering the remarkable similarity between the "Vista de la calle principal hasta el Centro Cívico" and the approach on Avenida 9 de Julio towards Buenos Aires' city center, the view of a Ciudad Azucarera's wide, tree-lined main street finished with a tall white rectangular building with a circular window at the top recalls the placement of the Obelisk as the focal point between the tree-lined meridians along the avenue. ${ }^{9}$ While the geometric forms are different-slab-like rectangle to slenderly tapered triangle and flat-laying circular window to sloped rectangular windows - the impression against the skyline is strikingly similar. As becomes

${ }^{9}$ See Figure 6. 
apparent in Vautier \& Prebisch's writing, which we will turn to shortly, aesthetic innovation was in service of a specific understanding of aesthetic tradition and its morality.

As Alicia Novick argues in "La ciudad como arquitectura: la Ciudad Azucarera de 1924", the plans for Ernesto Vautier and Alberto Prebisch's Ciudad Azucarera, constitute an aesthetic affirmation of order against the effusion of "[el] caos espacial y...los problemas morales y sociales suscitados por la metrópolis" (59) [(the) spatial chaos and...the moral and social problems caused by the metropolis], and moreover, an affirmation of urban order as a means to effective industrial production (66). These objectives are achieved in the Ciudad Azucarera through a design in which the various functions of the city (housing, industry, culture and government, etc.) are zoned into different areas and further subdivided into individual buildings, "conjuntos habitacionales" (69) in residential areas, which are then once more apportioned into individual houses or apartments through modulations into distinct types or forms. The city here functions as a system that functions based on the formal communication of between its units, the bonds formed between the members of the communities that live there, and around, "los valores religiosos y el peso de las tradiciones que centralizan y otorgan identidad a la vida urbana" (70). While, historically this architectural development was new in Argentina and considered avant-garde, as Novick argues, "El conjunto trata de resolver arquitectura y ciudad en un proyecto unitario que considera nuevos materiales y nuevas formas constructivas, pero la tradición y la innovación presentan en él fronteras difusas" [The group attempts to integrate architecture and city in a single project that considers new materials and new building forms, but here the line between tradition and innovation is diffuse], that is to say, the social values behind the architecture were catholic, patriarchal and upheld efficient industrial production (70). The political consequences of this, considering the kind of city this was to be--a sugar city--in a province notable for its long history of upholding slave labor and slave-like conditions on the sugar plantations, the separation of quarters, of the residential spaces from the 
administrative, commercial and cultural spaces effectively would have made it easier to isolate workers and police the boundaries and activities occurring in each space.

These questions are further developed in "Arquitectura: estética de un ingeniero", a text written by Le Corbusier and translated by Alberto Prebisch and published in the the forty-first, and one of the last issues of Martín Fierro: quincenal de arte y crítica libre. One of the few, if not the only, translated texts included in the three-year run of the magazine, the article lays out an argument for architectural innovation through modernism as means to a health and virtuosity on the individual and societal level. For this to be possible, says Le Corbusier, architects must become more like engineers — who, according to him, are "sanos y viriles, activos y útiles, morales y alegres"-in their way of building according to the demands of the material. These qualities come to them through their contact with the universal laws of physics and the materials those laws act upon: "Los ingenieros realizan arquitectura, porque emplean el cálculo que proviene de las leyes universales, y sus obras nos hacen sentir la armonía...al ejecutar el cálculo, se encuentra en estado de espíritu puro, y en tal estado de espíritu, el gusto sigue por caminos certeros." [Engineers achieve architecture because they employ the calculus of universal law, and their works instill a sense of harmony...one can find oneself in a state of purity of spirit in their calculations, and in such a state of spirit, taste follows a certain path]. However, for the purposes of this essay, the most striking aspect of Prebisch's translation of Le Corbusier's article is the language used to open and close the argument: "Cuestíon moral. La mentira es intolerable. Se perece en la mentira" [The moral question. Lies are intolerable. Death flourishes in lies.]. In this first sentence Le Corbusier marks the relationship between morality, health, and architecture, later continuing to argue for representation of the contemporary spirit in the streets and the city; the last phrases of his text demand a whole-scale urban cleaning effort beginning with architecture, "limpad las casas; unid vuestros esfuerzos para que reconstruyan ciudades...Decid bien, que la arquitectura requiere vuestra atención. Tened 
cuidado del problema de la arquitectura," [clean your houses; unite your efforts to rebuild cities...Speak well, because architecture requires your attention. Take care with the problem of architecture.]. While Le Corbusier's text was only translated by Prebisch, and not written in collaboration with him-as the magazine's table of contents would otherwise suggest - it can be argued that this article exercised influence on Prebisch during the years before the Obelisk's construction. Prebisch's own writing in Martín Fierro previous to this publication echoes the key tenets of Le Corbusier's piece, as in "Como decíamos ayer..."[As we were saying yesterday...], when he and Vautier demand a masculine engagement with art that would put aside questions of sensibility and nostalgia: "Arte y ciencia tienen cada uno de sus límites precisos. Pero si reconocemos la premura de establecer una distinción entre ambos, no podemos pasarnos de constatar la fuerza controladora y purificadora de la ciencia y de la industria ejerciéndose sobre el espíritu de los artistas conscientes." [Art and science each have their own precise limits. But if we recognize the haste to establish a distinction between the two, we cannot ignore the controlling and purifying force of science and industry exerting itself on the spirit of conscious artists]. Here the same language of purity achieved through science finds expression in the desire for seemingly incontrovertible scientific law, and the industry that puts science into practice, to guide the spirit to great artistic achievement.

Understanding the ideological coordinates behind Prebisch's (and Vautier's) urbanism is important to understanding the place of the Obelisk in late 1930s Buenos Aires and the city at the 400th anniversary of its foundation because the form of the monument and the approach to it from Avenida 9 de Julio are directly lifted from the Ciudad Azucarera plans. Vedia y Mitre's interest in a monument and and urbanism of these kinds demonstrates his intentions of making Buenos Aires a cleaner, more orderly, moral and rational city at the expense of residents and workers' ability to make demands on the city regarding how they lived and how they worked. 
CATEDRAL Tomada: Revista de crítica literaria latinoamericana / Journal of Latin American Literary Criticism Public works: Building a Monument to Modern Buenos Aires.

\section{The monument and the city.}

The Obelisk reflects on the city of Buenos Aires in the sense that the monument serves as a technology that creates a space of tension between an enduring idea of the city and a city desired and imagined by a coterie of politicians, architects and engineers. To some degree, the space of tension established by the monument was mediated by the historical relationship of the city to the nation, of Buenos Aires to Argentina, a relationship that the monument itself was built to recognize. Sitting on the site of the Church of San Nicolás de Bari, ${ }^{10}$ where the first Argentine flag had been raised, and on the newly christened Plaza de la República, the monument ties the project of modernizing the city to a project of modernizing the nation. As a technology, the Obelisk symbolically produces and regulates an idea of Buenos Aires that engages with its status as federal capital, but moreover intends to materialize their modernity on the one hand, by means of an aesthetic project, and on the other, the public works projects taking shape beneath its base. Considering the city through the Obelisk's perspective, then, cannot be done by looking out the monument's four windows. Rather, this kind of looking would have to take place from below, starting with the subterranean and surface spaces occupied by its visitors and inhabitants.

In this section, I would like to explore the idea of the monument as a technology through Roland Barthes' theorization of the relationship between monument, city and nation in his 1979 essay "The Eiffel Tower." Barthes' thinking has often been used in an Argentinean context to understand issues of perspective as relating to photography in nation and city-building projects. ${ }^{11}$ I will be using his framework in this case to understand monuments and the kind of

${ }^{10}$ See Figure 7.

11 Optic of the State by Jens Andermann; Argentine, Mexican, and Guatemalan Photography : Feminist, Queer, and Post-Masculinist Perspectives by David William Foster; Translocal Geographies : Spaces, Places, Connections by Ayona Datta and Katherine Brickell are just a few examples of books published in the last five years that engage with Barthes on the issue of perspective in an urban context in Argentina. 
perspective they establish around them in a will help us unravel two key issues: how the monument's perceived technological utility qualifies its value as a symbol of place and how the kinds of sight and movement called upon when thinking about the monument and the city determine the extent of its hegemony as the symbol of the city. Furthermore, Barthes' argument places the question of monumentality and the city in conversation with the relationship between the place of the capital city, in his case, Paris, and its monument, the Eiffel Tower, in establishing a national imaginary. In this section, I will read Barthes closely to establish a theoretical framework for understanding the Obelisk of Buenos Aires as a monument in its context in late 1930s Buenos Aires, Argentina and point ways in which a critical reflection on the Obelisk can provide alternative ways of thinking monuments, city and nation beyond Barthes.

Remarking on the metonymy of monument for both city and nation, Barthes speaks of the tower as standing in as "a universal symbol of Paris" and also in whose name "there is no journey to France which isn't made, somehow" (Barthes, 237); that is to say, the monument represents the city, but justifies foreign travel to the nation. Citing Maupassant -"It's the only place in Paris...where I don't have to see it" (236)- he signals a tension: that the Eiffel Tower is a place to which one goes to avoid the city but is also a place that unavoidably calls the city to mind. In this short text, Barthes thinks about the city in the shadow of the monument, emphasizing how the idea of the tower, together with how it operates within the space of Paris as a measure of distance and beacon towards the Champ de Mars serves to support the tower's contested technological modernity. Despite the foregrounded role of the engineer in the construction of the Eiffel Tower, the monument remains tied to its scientific "uselessness" 12 as the feats of engineering showcased during the 1889 World's Fair were left to sit

\footnotetext{
12 "The tower's inutility has always been obscurely felt to be a scandal, i.e., a truth, one that is precious and inadmissible. Even before it was built, it was blamed for being useless, which, it was believed at the time, was sufficient to condemn it; it was not in the spirit of a period commonly dedicated to rationality and to the empiricism of great bourgeois enterprises to endure the notion of a useless object (unless it was declaratively an objet d'art, which was also unthinkable in relation to the Tower" (238).
} 
with the imagination and had no other operative function of benefit to the inhabitants of Paris. And yet, as Barthes notes, Eiffel and his defenders employed a kind of utopian rhetoric that redefined Paris as a "temple of Science" (240), linking the idea of the monument to a dream of organizing the city following the principles of nature. In practice, the monument has organized the imaginary of the city around itself-- movement through physical space can be visually oriented according to one's position around the tower and the city's districts can be classified and qualified when viewed from up top. These dynamics are abundantly clear in Barthes essay, but what they mean for political engagement with the monument, the city's space or even what the changed orientation of the city means for the space of France, is unclear.

The Obelisk of Buenos Aires, built some fifty years after the Eiffel Tower, and forty years before Barthes' essay was published, does not, from its façade evoke a project of engineering modernity. Not hewn from a single stone, but rather built with smaller white brick-like stones around a hollow core with stairs and rest platforms inside leading up to an indoor viewing deck, it departs from the paradigm of the Egyptian obelisk. To be clear, the Obelisk falls in line with a series of other obelisks built throughout the Americas in its deviation from the standard, ${ }^{13}$ but differs from its geographical peers granted that a great majority these obelisks were built to commemorate important figures and battles in each

\footnotetext{
${ }^{13}$ Another example of this is the Obelisco de los Constituyentes in Montevideo, Uruguay, built only six years before the Obelisk of Buenos Aires. In "Obeliscos americanos: polêmicos da gênese à forma," Margaret M. Bakos, alongside Márcia Raquel de Brito and Bartira Machado da Silva, understand the popularity of the Obelisk form as part of a late 19th and early 20th century Egyptomania in Latin America, North America and Europe--the New York and London Cleopatra's Needles and the Luxor Obelisk are perhaps more notable cases of this. However, they also link the popularity of the obelisk form to its sustained definition, following Le Goff, " $a$ celebração através de um monumento comemorativo de un acontecimento memorável"-- a celebration of a memorable event through a commemorative monument (Bakos et al, 197). Vedia y Mitre himself was caught up in the Egyptomania of the period--as Christian Ferrer notes in his article, "Vertical: La ciudad y los emblemas de poder," the then-Intendente had published his translation of Oscar Wilde's poem, "The Sphinx" (1894) some ten years before his monument was erected.
} 
country's wars of independence. ${ }^{14}$ As stated previously, the Buenos Aires Obelisk pays homage to the foundation of the republic through its location on the Plaza de la República and the site where the first Argentine flag was raised. However, its avowed purpose, as inscribed on its eastern side, is to celebrate the foundation of the city some two hundred years prior. ${ }^{15}$

In its departure from the established definition of an obelisk it permits a series of interactions with the city that draw it in line with the public works projects occurring around it. Early histories of the Obelisk chronicle how the monument's contested formal status as an obelisk dogged its first years at the city's center, likely a correlate to dissatisfaction with the mayor, Mariano de Vedia y Mitre's surprise decision place an anachronistic monument at the crossing of four of the city's largest ongoing infrastructure projects at the time-the Avenida Nueve de Julio, the continuation of the Avenida Roque Saenz Peña and the construction of the $\mathrm{C}$ line of the subway and the underground connecting plaza between all three C, D and B lines ${ }^{16}$. It's technological novelty, however, resides in its emplacement on the 14-lane Avenida Nueve de Julio and the threeline subway crossing directly beneath it. Its neoclassicism both effectively masks the technological endeavors underway at its base and beneath it and and ties the

\footnotetext{
${ }^{14}$ Examples of this are the Washington Monument in the United States, the Obelisk of Barismeto, Venezuela, the Obelisk of Iberapuera in São Paulo, Brazil and the Obelisk of Ayacucho in Peru. The Pirámide de Mayo in the Plaza de Mayo, located a scant few blocks away from the Obelisk, is another obelisk commemorating the May Revolution in 1811, which began Argentina's War of Independence.

${ }^{15}$ The inscription states, "Buenos Aires a la República/ En el IV Centenario de la fundación/de la ciudad por/Don Pedro de Mendoza. /II de Febrero de MDXXXVI." Inscriptions on the other three sides of the monument describe the historical importance of the site to the nation, "En este sitio/en la torre de San Nicolás/fue izada por primera vez,en la ciudad/la Bandera Nacional/el XXIII de agosto de/MDCCCXI," as stated on the north side; the second foundation of the city by Juan de Garay, "Segunda Fundación por/Juan de Garay/ XI de junio de MDLXXX," on the south side; and finally the juridical relationship of city and republic, located on the monument's western face, "Capital Federal/Ley dictada por el Congreso Nacional/el XX de septiembre de MDCCCLXXX/a iniciativa del Presidente/Nicolás Avellaneda/Decreto del Presidente Julio A. Roca/VI de diciembre de MDCCCLXXX." See Figures 3-6.

${ }^{16}$ Vladimir Reznichenko and Magdalena D. M. de Ayerza summarize these debates in their respective articles.
} 
new urban infrastructure back to an image of a purported origin of Western civilization.

One of the interactions the hollow core of the Obelisk allows for is the establishment of an impossibility. Given that access to the interior of the monument has been barred to all those except for a series of experts and technicians with special permission from the city--engineers, painters, urbanists, builders, journalists and the occasional person of notoriety--the desire to be one of the few to reach the top to look out over the center of Buenos Aires from the viewing deck has grown into a cultural trope, played out recurringly in film, art and performance production since the monument's construction in $1936 .{ }^{17}$ As the Obelisk sequence from Pizza, Birra, Faso summarized in the introduction to this paper illustrates, there are always exceptions and examples of the adventurous breaking in, but these exceptions in themselves speak to the attractiveness of this privileged and exclusive space and the perspective onto the city that it offers. This is not to say that the views are especially extensive. As the documentation from Leandro Erlich's La democracia del símbolo shows, ${ }^{18}$ the views from the windows are essentially fixed onto Avenida Corrientes and Nueve de Julio and the buildings that border them and only show a rather short extent of the long Avenues' range and the city around them. ${ }^{19}$ Accordingly, one of the most conspicuous of the Obelisk's perspectives onto Buenos Aires is fraught with the difficulty of discerning the city beyond the infrastructure.

Yet, this particular difficulty, from one position, becomes an advantage when positioned differently around the monument. As previously stated, the Obelisk establishes a range of perspectives that can be actualized both at surface level and underground. These perspectives put in motion a series of desires

\footnotetext{
${ }^{17}$ Marta Minujín's series of Obelisks -El Obelisco Dulce (1964), El Obelisco Acostado (1978), El Obelisco de Pan Dulce (1979), Obelisco Plateado y Multidireccional (2009)- are notable examples. In 1989 the Argentine performance group La Organización Negra performed La tirolesa, a show in which performers dropped from and moved around the Obelisk to loud drumming.

${ }^{18}$ See Figures 8 and 9.

${ }^{19}$ See Figure 10.
} 
dependent on the relationship between monument and city, like the desire to see Buenos Aires from a bird's-eye or near bird's-eye perspective. Moreover, the range of perspective around the Obelisk, demarcated by the buildings surrounding it, forecloses the possibility of visually engaging with the physical monument from beyond the sightlines established by the avenues. This is to say that the Obelisk, from the surface-level of the city does not link distinct parts of the city to each other from a distance. It does not unite the city and does not establish a common meaning by attracting the gaze of those occupying the space of the city. Rather, the Obelisk unites the city from the avenues that intersect around it and the subway system that radiates out from beneath it. Accordingly, we can understand that the monument is significant in terms of a political imaginary in that its currency as a symbol is sustained by the many quotidian actions that occur around it--though there were concrete figures behind its establishment in the city, continued engagement with the monument by a host of organizations and individuals have brought it forward as a way of seeing and envisioning the future of Buenos Aires.

Barthes' argument on the role of monuments and monumentality in thinking about the city is an important contribution to understanding the relationship between the monument form, technology, and the space of the city and nation. His argument gestures towards a politics of the Eiffel Tower as it relates to how its novelty, and later symbolic status transformed the kinds of space the monument is embedded in. For Barthes, the monument is a site of pilgrimage, of faith and of the sacred, that nevertheless is tied to the an understanding of the city as market. National geography separates those devotees who have yet to establish themselves in the city, and who intend to remake it again in their image-the monument replicates the possibility of itself as a technology for rethinking the city, but leaves that possibility open to only ambitious, young, and presumably white, provincial men. The Obelisk intends to be a marker of an orderly, moral and rational city, but in its indelible relationship to the subway underneath its foundation and the avenues that connect around it, the monument can also be 
thought of as a symbol of the interactions between those who congregate and transit around it, by those who sleep and work around and under it. Taken from below, as a symbol it is also consumed as a space open to those who can either pay the fare, safely jump the turnstile or make it to the center of Buenos Aires.

\section{Conclusions}

The ragtag group that makes it to the top of the Obelisk in Adrián Caetano and Bruno Stagnaro's 1998 film Pizza, Birra, Faso ultimately sees very little -as the character Trompa remarks, "No se ve ni un carajo" (You can't see shit). And yet, as he speaks, the viewer can see city lights out the window, and in another shot, the endless procession of cars down Avenida Nueve de Julio and the 25 de Mayo highway that crosses it in the distance. Finally, Córdoba, another one of the group, stands up and looks out the window, only to see his wife, Sandra, handcuffed and being taken away by the police, the performer that Córdoba and Trompa had robbed earlier having singled her out as perpetrator.

The Obelisk currently sits on top of the largest subway crossing in the city, encompassing three subway stops of three different lines -Carlos Pellegrini (B line), Diagonal Norte (C line), and Nueve de Julio (D line). The Plaza de la República on which the Obelisk stands mirrors an underground plaza and market across which a flood of people arrive, depart, transfer trains and buy and sell merchandise either in the stands established in the market below or off of their carts and by foot. Whereas on the surface of the city, the Obelisk is an almost impenetrable monument whose observation deck is closed off to all except the lucky few, underground, anyone who uses the subway system has the Obelisk open to them. Though this kind of entryway limits the availability of a more privileged, yet not quite birds-eye-view of the city, it does recontextualize the monument and its space in terms of the masses of people that transit around the 
Obelisk every day, that set up camp around it to demand slum urbanization, ${ }^{20}$ that march by the Obelisk en route to the Plaza de Mayo, catching it in their flood, almost as if to bring it with them as a reminder of what the city is to the nation.

In the decades prior to the Obelisk's construction, and especially the few years before its emergence in the city center, Buenos Aires had undergone rapid and deep changes transformed it from being la Gran Aldea to projecting itself as one of the most modern cities in the world. While a significant part of these changes occurred thanks to the city's demographic and spatial expansion, new kinds of services and infrastructures were introduced that were not immune from the reactionary positivism shrouding most debates on the direction in which to lead the city of the future. ${ }^{21}$ The public works continued and undertaken during the time of the Obelisk's construction were all monumental projects in and of themselves, there was no material symbol to herald and represent the construction of the city of the future, and no means of interpreting what these projects could mean on a national scale. In the three sections of this paper, I have reflected on how, placing the Obelisk in the context of the public works projects taking place around Buenos Aires' fourth centennial, we can understand the monument as a city-making technology. Through a brief history of the city of Buenos Aires prior to the monument's construction, a critical evaluation of the relationship between Alberto Prebisch's unrealized project for the sugar workers' city in Tucumán and the project of urban renewal in Buenos Aires' center, and ultimately a theorization of the Obelisk's way of interacting with the new Buenos Aires it was meant to symbolize, I have argued that Obelisk of Buenos Aires is only accessible as a symbol and perspective onto the city when accessed from the concrete public works projects that it was meant to represent. So, what can be seen from the

${ }^{20}$ Here I am referring to the Corriente Independiente Villera's 2014 encampment around the Obelisk, dubbed "Villa Obelisco" and "Carpa Obelisco" that demanded urbanization of all slums in Buenos Aires. See Notas, Clarín and Infobae articles.

${ }^{21}$ In El color del río: historia cultural del paisaje del riachuelo, Graciela Silvestri gives a detailed account of how demographic growth from the late 19th Century to the early-mid 20th Century impacted the built environment of Buenos Aires, especially in the port areas at the city's eastern edge. 
CATEDRAL TOMADA: Revista de crítica literaria latinoamericana / Journal of Latin American Literary Criticism Public works: Building a Monument to Modern Buenos Aires.

windows of the Obelisk? Nothing, except, perhaps the unforgiving repetition of floods of people, cars and buses.

\section{Annex}

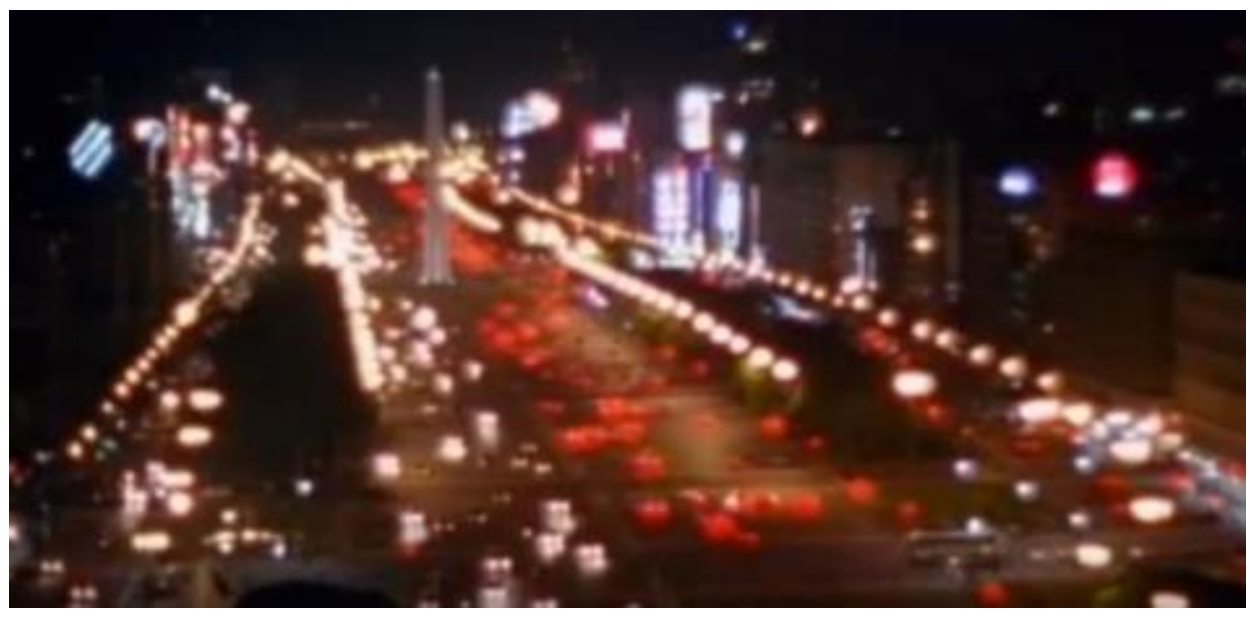

Ilustración 1. Still from Pizza, Birra, Faso dir. Adrián Caetano and Bruno Stagnaro. Min. 6:01. 
CATEDRAL TomadA: Revista literaria latinoamericana / Journal of Latin American Literary Criticism Anayvelyse Allen-Mossman

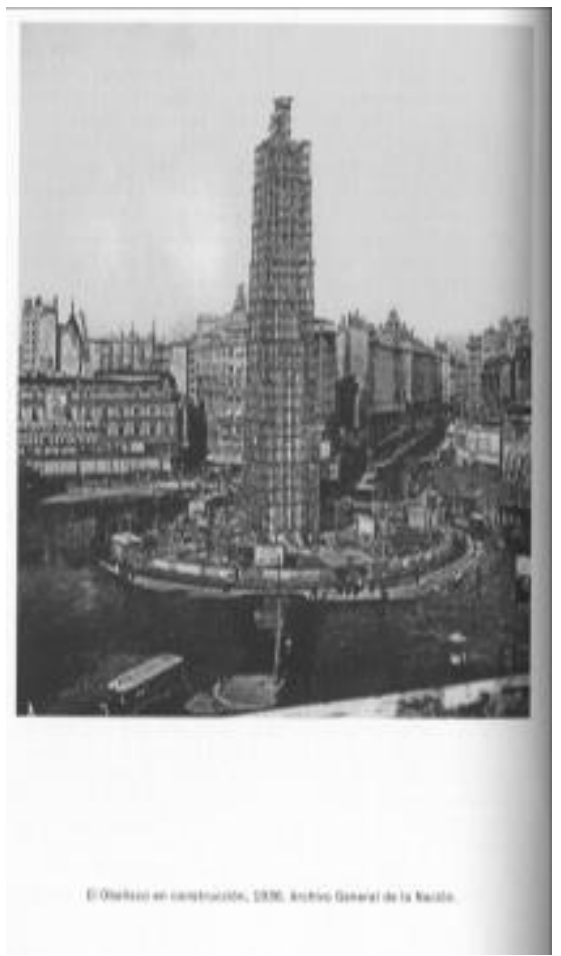

Ilustración 2. The Obelisk Under Construction, 1936. Found in La democracia del símbolo (Erlich, 2015, pg. 14), from Archivo General de la Nación Argentina.

Figures 3-7. Images of the four sides of the Obelisk and their inscriptions in the following order. From Wikimedia Commons. 
CATEDRAL Tomada: Revista de crítica literaria latinoamericana / Journal of Latin American Literary Criticism Public works: Building a Monument to Modern Buenos Aires.

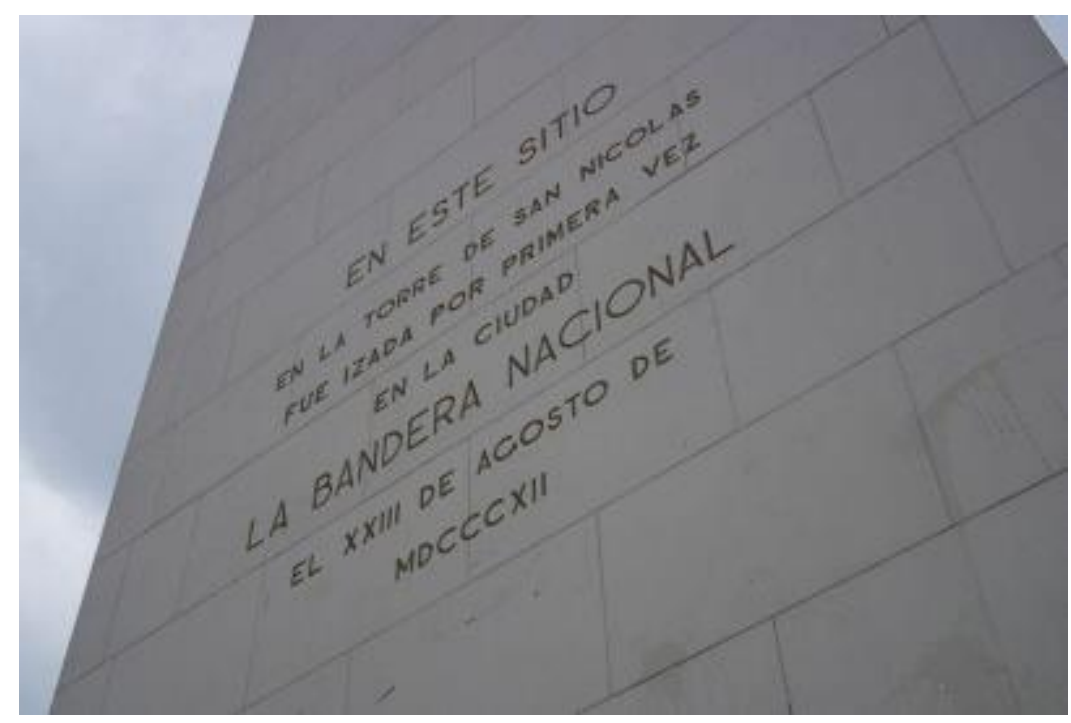

Ilustración 3. Obelisk's North Face.

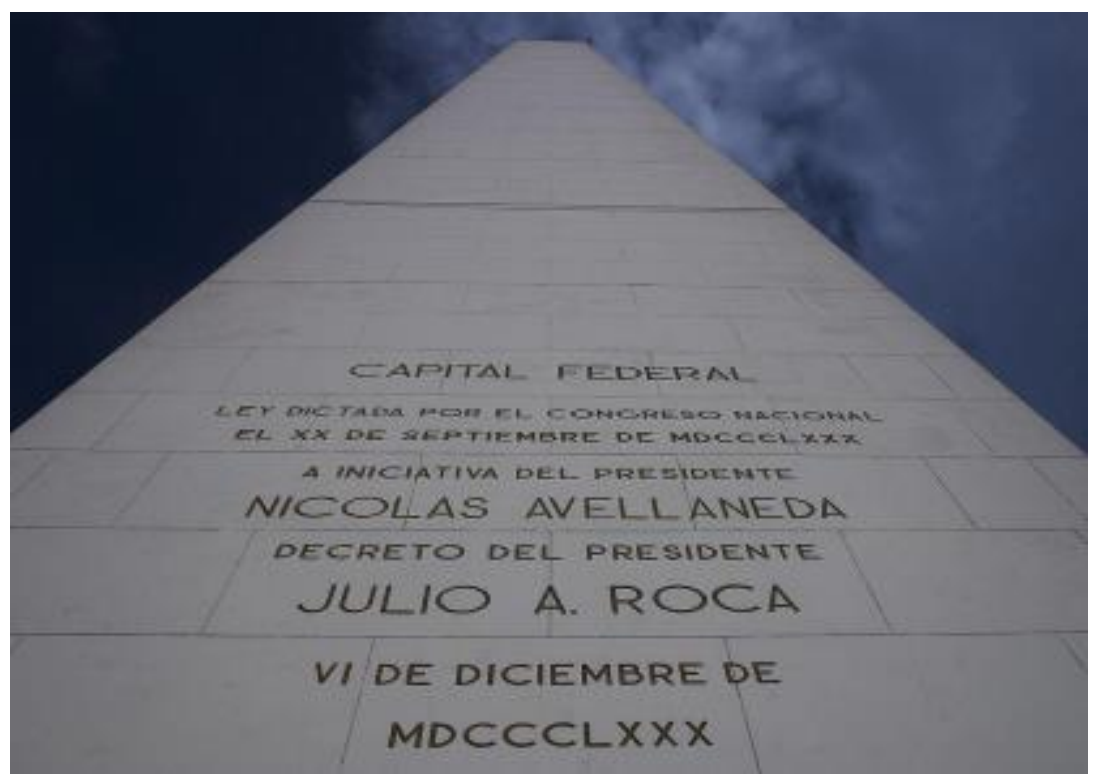

Ilustración 4. Obelisk's West Face. 


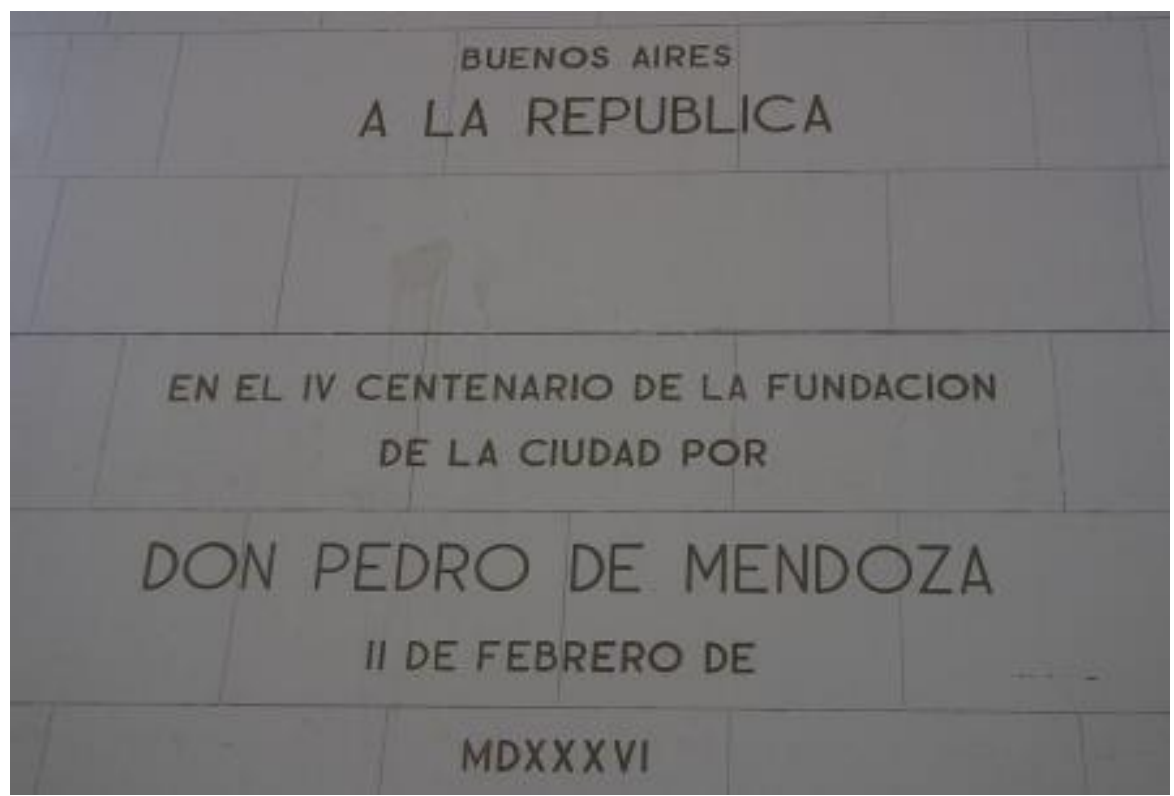

Ilustración 5. Obelisk's East Face.

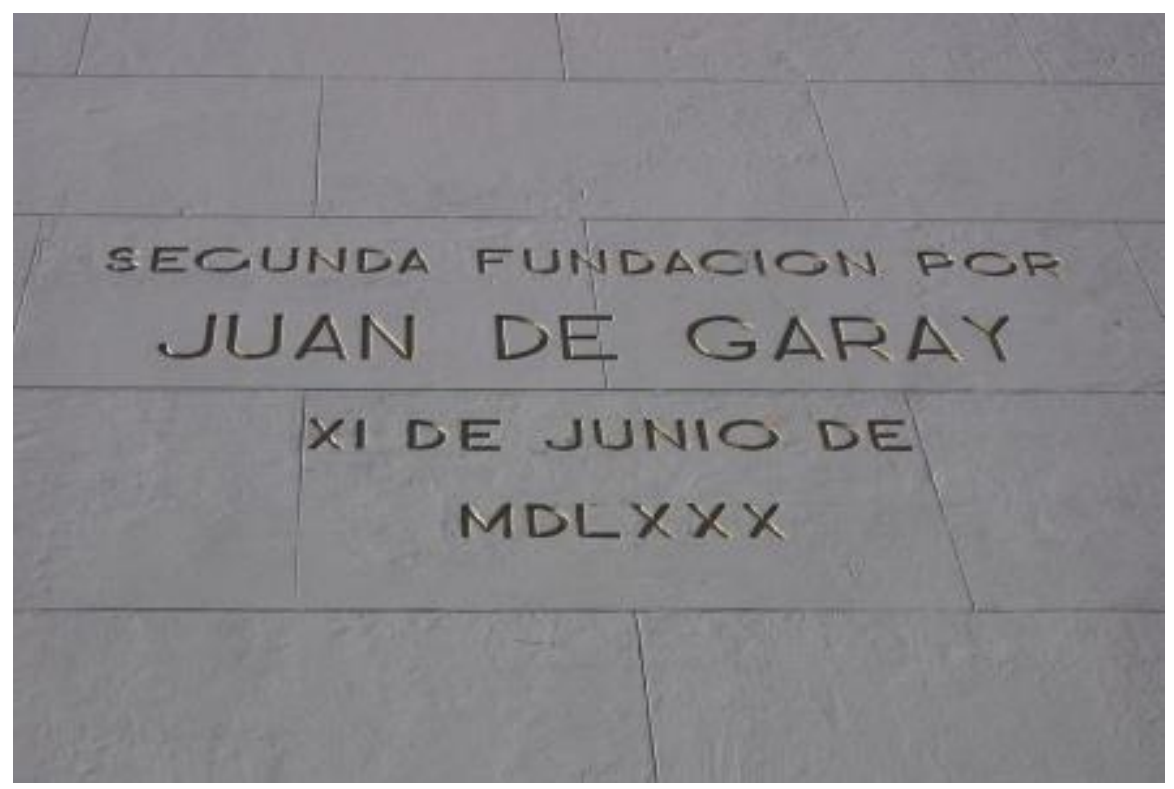

Ilustración 6. Obelisk's South Face. 


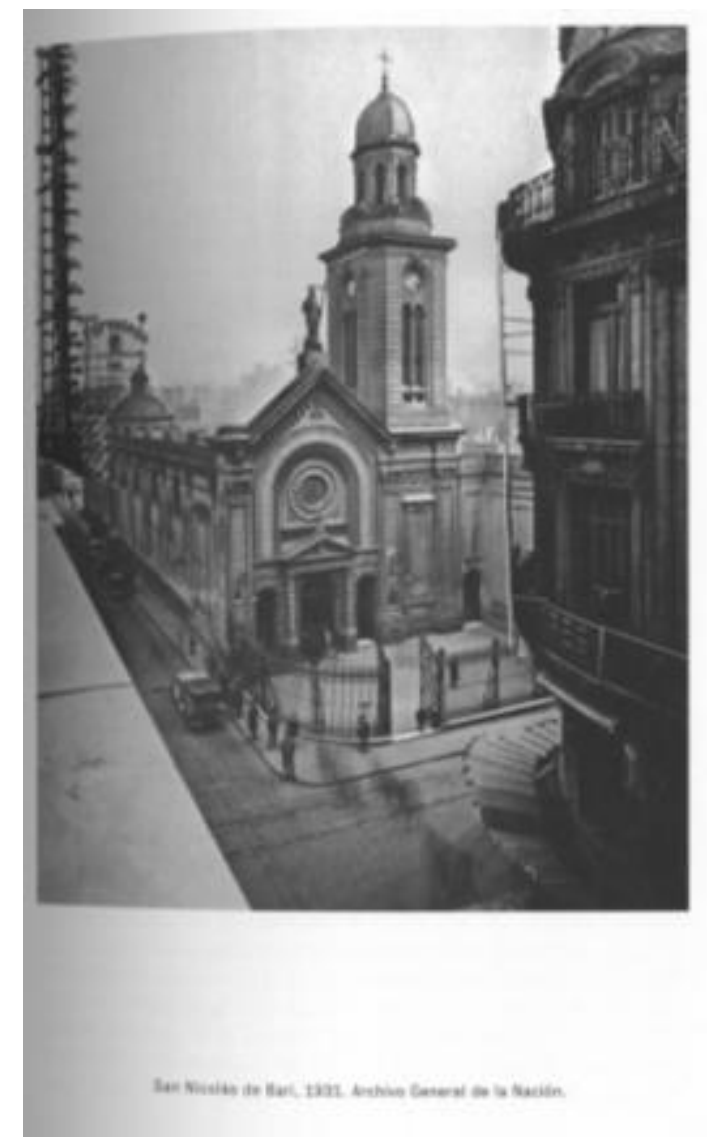

Ilustración 7. Image of the Church of San Nicolás de Bari. Found in La democracia del símbolo (Erlich, 2015, pg. 19), from Archivo General de la Nación Argentina. 


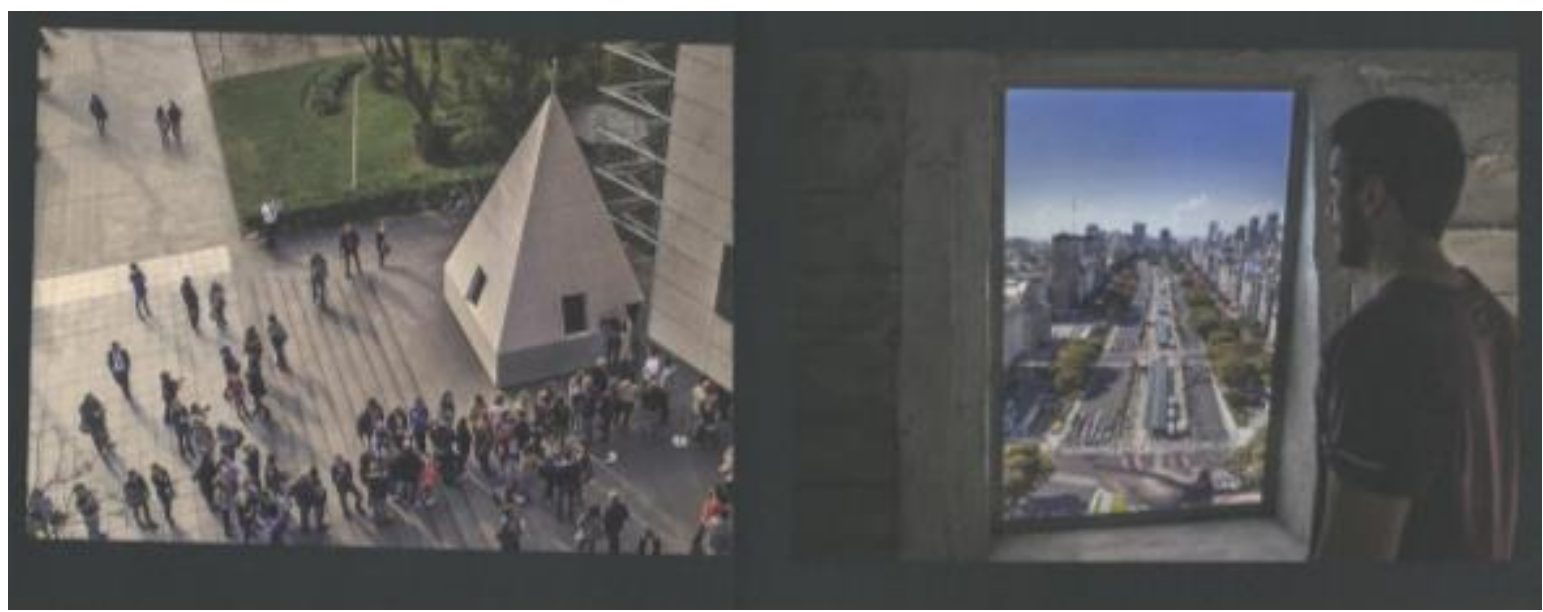

Ilustración 8. Interior view from inside of the reproduction of the tip of the Obelisk. Image from La democracia del símbolo, Leandro Erlich (foldout sheet).

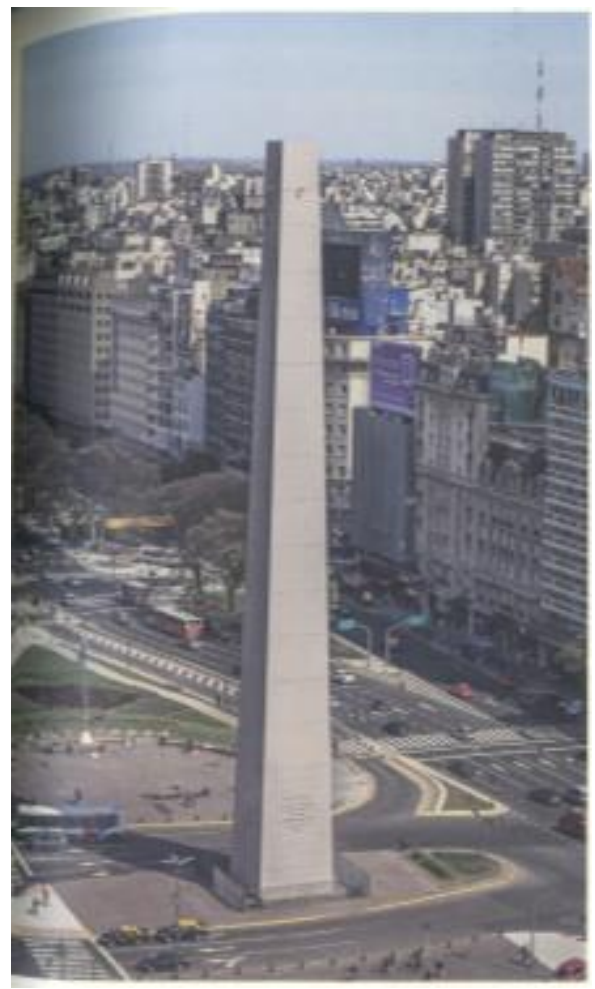

Ilustración 9. View from Avenida Nueve de Julio of the Obelisk after Erlich's intervention. Image from $\mathbf{L a}$ democracia del símbolo, Leandro Erlich. 


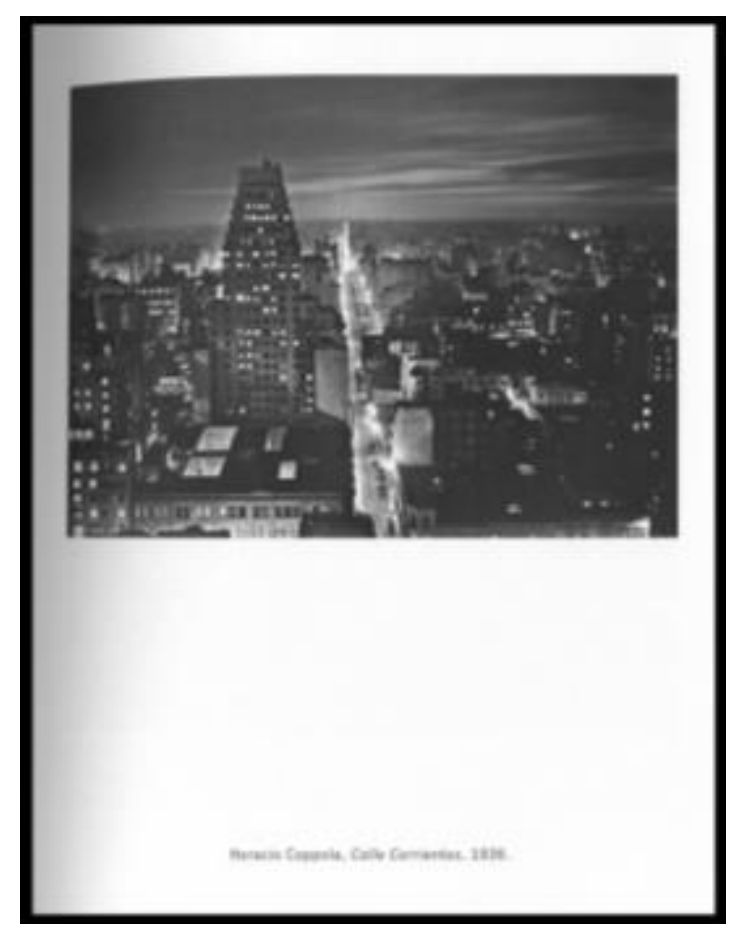

Ilustración 10. "Calle Corrientes" by Horacio Coppola, 1936. Found in La democracia del símbolo (Erlich, 2015, pg. 41).

\section{Bibliography}

"La Organización Negra. Biografía." La Organización Negra. Biografía. Centro Visual De Arte Argentino, Centro Cultural Recoleta, n.d. Web. 15 July 2016.

"Las Múltiples Miradas De Minujín Sobre El Obelisco, Un ícono Porteño."Clarín Ciudades. Clarín, 13 Feb. 2011. Web. 15 July 216.

"Obelisco." Sitio Oficial De Turismo De La Ciudad De Buenos Aires. Buenos Aires Ciudad, n.d. Web. 29 May 2015. 
"Pirámide De Mayo." Sitio Oficial De Turismo De La Ciudad De Buenos Aires. Buenos Aires Ciudad, n.d. Web. 29 May 2015.

"Segunda Semana De La Carpa Villera." Notas. Notas.org.ar, 28 Apr. 2014. Web. 19 July 2016.

"Triunfo De La Carpa Villera." Notas. Notas.org.ar, 12 June 2014. Web. 19 July 2016.

"Villa Obelisco, El Asentamiento Que Crece En El Centro Porteño."Infobae.com. Infobae, 10 June 2014. Web. 19 July 2016.

"Villa Obelisco", Una Protesta Que Crece Día a Día." Clarín Ciudades. Clarín.com, 11 June 2014. Web. 19 July 2016.

Andermann, Jens. The Optic of the State: Visuality and Power in Argentina and Brazil. Pittsburgh: U of Pittsburgh, 2007. Print.

Armus, Diego. The Ailing City: Health, Tuberculosis, and Culture in Buenos Aires, 1870-1950. Durham: Duke UP, 2011. Print.

Barthes, Roland. The Eiffel Tower, and Other Mythologies. New York: Hill and Wang, 1979. Print.

Barcex. Fachada oeste del Obelisco de Buenos Aires, que recuerda la federalización de la ciudad, Buenos Aires, Argentina. 2006. Buenos Aires. Wikipedia. The Free Encyclopedia. Web. 29 July 2016.

Barcex. Fachada sur del Obelisco de Buenos Aires, que recuerda la segunda fundación de la ciudad (1580), Buenos Aires, Argentina. 2006. Buenos Aires. Wikipedia. The Free Encyclopedia. Web. 29 July 2016.

Barcex. Fachada Norte Del Obelisco De Buenos Aires, Que Recuerda La Primera Vez Que Se Izó La Bandera Nacional En La Ciudad (1812), Buenos Aires, Argentina. 2006. Buenos Aires. Wikipedia. The Free Encyclopedia. Web. 29 July 2016.

Barcex. Fachada este del Obelisco de Buenos Aires, que recuerda el cuarto centenario de la fundación de la ciudad, Buenos Aires, Argentina. 2006. Buenos Aires. Wikipedia. The Free Encyclopedia. Web. 29 July 2016.

Bakos, Margaret M., Márcia Raquel De Brito, and Bartira Machado Da Silva. "Obeliscos Americanos: Polêmicos Da Gênese à Forma." Phoînix (2004): 195-99. Google Books. Google. Web. 15 July 2016.

Brickell, Katherine, and Ayona Datta. Translocal Geographies: Spaces, Places, Connections. Farnham: Ashgate, 2011. Print.

Casanovas, Laura. "Marta Minujin Presentó Un Obelisco Propio Y Múltiple." La Nación: Cultura. La Nación, 1 Sept. 2009. Web. 15 July 2016. 
Curran, Brian A. Obelisk: A History. Cambridge, MA: Burndy Library, 2009. Print.

De Ayerza, Magdalena D.M. "El Obelisco Y Sus Polemicas." Todo Es Historia 31.367 (1998): 50-56. HAPI. Web. 4 May 2016.

De Vedia Y Mitre, Mariano. De Rivadavia a Rosas. Buenos Aires: El Ateneo, 1930. Print.

- El Régimen Tributario De La Argentina; Estudio Constitucional, Económico Y Financiero Del Sistema Impositivo De La Nación, Las Provincias Y Las Municipalidades. Buenos Aires: Imprenta De La Universidad, 1925. Print.

. Historia De La Unidad Nacional. Buenos Aires: A. Estrada, 1952. Print. . La Vida De Monteagudo. Buenos Aires: G. Kraft, 1950. Print.

Erlich, Leandro. La Democracia Del Símbolo. Buenos Aires: Socorro Giménez Cubillos/MALBA, 2015. Print.

Foster, David William. Argentine, Mexican, and Guatemalan Photography: Feminist, Queer, and Post-masculinist Perspectives. Austin: U of Texas, 2014. Print.

Gorelik, Adrián. "La Ciudad Y La Historia: Primer Cumpleanos." La Grilla Y El Parque: Espacio Público Y Cultura Urbana En Buenos Aires, 1887-1936. Buenos Aires: Universidad Nacional De Quilmes, 1998. 181-235. Print.

Jeanneret-Gris, Charles-Édouard. "Arquitectura: Estética De Un Ingeniero." Trans. Alberto Prebisch. Martín Fierro, Quincenal De Arte Y Crítica Libre 28 May 1927: n. pag. Print.

Ministerio De Turismo De La Nación. "EL OBELISCO, EL MÁXIMO SÍMBOLO DE BUENOS AIRES." Sindicato Unificado De Trabajadores De La Educación De Buenos Aires: Notas De Interés. SUTEBA, n.d. Web. 29 May 2015.

Minujin, Marta, and Victoria Noorthoorn. Marta Minujín: Obras 1959-1989. Buenos Aires, Argentina: Malba-Fundación Constantini, 2010. Print.

Novak, Alicia. "La Ciudad Como Arquitectura: La Cité Azucarera De 1924." Alberto Prebisch : Una Vanguardia Con Tradicion. Ed. Ramón Gutierrez. Buenos Aires: Fundación CEDODAL, 1999. 58-71. Print.

Baldinu, Pichón, and Gabriela Baldini. "La Tirolesa - La Organización Negra."YouTube. YouTube, 30 Aug. 2011. Web. 15 July 2016.

Pizza Birra Faso. Dir. Bruno Stagnaro and Israel Adrián Caetano. Prod. Carolina Aldao. Perf. 
Hector Anglada, Jorge Sesan, Pamela Jordán, Alejandro Pous, Walter Díaz, Adrian Yospe, Daniel Dibiase, Rubén Rodríguez, Martín Adjemián. Cinemateca, 2005. DVD.

Pillado, J. A., Juan Pelleschi, and S. Obligado. La Pirámide De Mayo: Informe Presentado Á La Junta De Historia Y Numismática Americana Por La Comisión Encargada De Investigar La Existencia Del Primitivo Obelisco Dentro Del Actual. Buenos Aires: Compañía Sud-Americana De Billetes De Banco, 1913. Print.

Prebisch, Alberto, and Ernesto Vautier. "Cómo Decíamos Ayer..." Martín Fierro, Quincenal De Arte Y Crítica Libre 1925: n. pag. Print.

Reznichenko, Vladimir. "Alrededor Del Obelisco: Trazos Sobre El Paisaje De Buenos Aires." América Latina (USSR) 4 (1986): 83-91. HAPI. Web. 4 May 2016.

Sabugo, Mario. "El Obelisco De Arriba Abajo." Summa+ 91 (2007): 166-67. Summa. Donn S. A., 1 Dec. 2007. Web. 29 May 2015.

Silvestri, Graciela. El Color Del Río: Historia Cultural Del Paisaje Del Riachuelo. Buenos Aires: Universidad Nacional De Quilmes, 2003. Print.

Walter, Richard J. Politics and Urban Growth in Buenos Aires, 1910-1942. Cambridge: Cambridge UP, 1993. Print. 